thin lamina perpendicular to the camera axis was photographed (Harold. White, for the Power Gas Corporation, Ltd.). The Bowater Paper Corporation, Ltd., exhibited a print taken at 1/8000th of a second showing the fluid pulp on the wire mesh of a papermaking machine.

Other pictures showed the use of enamel for revealing the pattern of strain in metals (A. V. Roe, Ltd.), photoelastic stress patterns in gears and pawls (International Computers and Tabulators, Ltd.), the ultrasonic testing of metals (Steel Co. of Wales) and recording of cracks in concrete (Babcock and Wilcox, Ltd.). The last firm also showed photomicrographs of metal structure.

Probably the stand which was best arranged to enlighten the hypothetical executive was that of Pye, Ltd. It was divided into a series of cubicles, each one of which showed an application of closedeircuit television, such as the transmission of printed. information or instrument dial readings or the examination of machinery in operation in inaccessible or inconvenient positions. Details were also given of a special camera designed to operate inside a nuclear reactor. Similar equipment was also exhibited by Marconi Wireless Telegraph Co., Ltd., for traffic observation and control.

Rank Cintel, Ltd., were demonstrating a threechannel colour-television apparatus and a video tape recorder. They also showed how television techniques could be applied to photographic printers and enlargers to adjust the contrast of a negative to improve print quality.

Decca, Ltd., showed a data-transmitting system which used a cathode-ray tube as a scanner with a photomultiplier pick-up tube.
The three photographic firms who exhibited featured document copying and reproduction. Gevaert, Ltd., showed examples of the 'Gevacopy' process which utilizes silver image transfer for producing a few copies. If a larger number are required then an offset printing plate on aluminium can be prepared. Ilford, Ltd., demonstrated a range of machines for using 'Azoflex' paper. This is a dye-coupling process which is capable of producing either as small or as large a number of copies as needed. On the Kodak stand was to be found the 'Verifax' process. This uses a layer which is hardened by light and afterwards pigmented. Any unhardened gelatine on the 'negative' can be transferred, more than once, to other sheets of paper to obtain several copies. Also shown on this stand were the 'Statfile' and 'Recordak' machines. A new model of the latter enables both sides of a sheet of printed material to be recorded side by side on a strip of film in one passage through the machine.

These firms also showed examples of radiography, colour transparencies and prints, etc., illustrating their uses in various fields. Ilford, Ltd., had a compact processing unit for $35,45,60$ and $70 \mathrm{~mm}$. film, which should be very useful to laboratories which employ oscillograph recorders, etc.

On other stands a wide variety of photographic equipment and chemicals could be seen : cameras (still and ciné), lenses, lighting units, timers, printers, enlargers, etc. John Hadland and Co. offered a complete service for high-speed photography. Many stands offered projectors for still and ciné pictures, with and without a commentary in sound for instruction, sales promotion, demonstration and advertising.

R. J. HeRCOCK

\title{
CHELSEA COLLEGE OF SCIENCE AND TECHNOLOGY
}

\section{NEW BUILDING}

\begin{abstract}
1 NEW wing was opened at Chelsea College of A Science and Technology on April 28 by Lord Adrian. The building was planned a number of years ago before the status of the College was changed and is thus relatively small and does not allow for any increase in social amenities for the College. Plans for further buildings on adjacent sites which will provide residential and social accommodation as well as a completely new Department of Chemistry are already well advanced. A new independent College of Art is also to be built opposite the present College building. In due course the School of Art, which now forms part of the College, will occupy the new building and release accommodation which will be adapted for use by the remaining departments of the College.
\end{abstract}

The present extension, which provides an additional floor area of 17,913 sq. ft., takes the form of a fourstory block running roughly from east to west and facing north to Chelsea Square, with a two-story addition facing inwards to the courtyard of the College. A gap on the second floor of the old West Wing has also been closed by the building of a new zoological laboratory and a smaller staff research laboratory. The main new building provides a laboratory, lecture room, and two store-rooms for physics, six classrooms, staff and office accommodation for mathematics, a large teaching laboratory, two research laboratories, a balance room and a lecture room for chemistry, and a studio, lithography room, store and students' rest room for art. A new students' common room is also provided, but this and the new Art School accommodation is merely exchanged for equivalent space vacated for use by the Department of Botany and Zoology and the College Library. Other rooms vacated by departments occupying the new wing will also be adapted for use by the School of Pharmacy and the Departments of Geology, Physiology and Pharmacology.

In introducing Lord Adrian, the chairman of the Governing Body, Mr. John Townsend, directed attention to the fact that the College was the only college of advanced technology which did not possess an engineering department and the only one which did possess a department of physiology. Lord Adrian referred to the important and expanding fields of training and research which come within the scope of the work of the College. While the need for many more trained engineers was well recognized, there was some danger of neglect of the biological side. Chelsea was well placed, with its large School of Pharmacy and its other science departments, to help in satisfying this need. He likened the present boom period for science to the time when Gresham College was founded in the City of London and the Royal
Society began its existence. At that time there was 
no clear distinction between science and technology and many famous men exemplified the union of the two in their own work. The distinction began to be emphasized in the nineteenth century but now it was growing out of date again; advances could come from either direction-the demand for a prettier stocking might lead to new theories of molecular structure or the new theories might lead to now fabrics. He congratulated the students of the College on having chosen a scientific career at this exciting period of expansion and emphasized the great possibilities that lay before them.

After declaring the extensions open, Lord Adrian inspected the new buildings, and the whole of the College was thrown open to visitors.

N. M. H. LightFoot

\section{ADMISSION OF STUDENTS TO UNIVERSITIES}

\begin{abstract}
$\mathrm{O}$ E of the most notable contributions in the report* of the vice-chancellor of the University of Birmingham for 1958 is his account of admissions procedure. Students are chosen by the faculty admission tutors in consultation with the heads of departments. The process goes on from January every year (or earlier) until September. Applications come from all over Britain, and from overseas, in numbers far exceeding the available places. Many are from candidates simultaneously applying to other universities as well, often with a preference for Oxford or Cambridge. They furnish school records, and headmasters' and headmistresses' assessments; many of them are brought to the universities for interview. More often than not the crucial information about applicants, namely, their performance in the ' $A$ ' level examinations for the General Certificate of Education, is not available until mid-August, but it is impracticable to leave all decisions until that late date. Tentatively, at least, the university must make most of its choice before then, while the candidate also wants to exercise his choice among universities. The result is that a complicated and haphazard system of provisional offers of admission has grown up, in which the universities compete for what they think are good candidates and the candidates compete for what they think are good universities. The universities often keep the candidates on tenterhooks and the candidates sometimes treat the universities in cavalier fashion.
\end{abstract}

* University of Birmingham. Report of the Vice-Chancellor and Principal for the Calendar Year 1958. Pp. 26. (Birmingham: The University, 1959.
The position has grown worse in the past three years, and threatens to grow worse still as numbers and competition increase. No smooth and tidy system seems possible so long as General Certificate examinations are held in June and university sessions begin in Oetober ; if those events were to be separated by a longer interval of time, no one can think how to occupy the boys and girls during that interval, short of imposing some kind of civilian national service. In studying the difficulty, however, the Committee of Vice-Chancellors and Principals concluded that it could at least be mitigated, and in June 1958 the Committee made a series of recom. mendations to the universities (other than Oxford and Cambridge) designed to smooth the path of university applicants to a considerable extent. It asked, among other things, that application forms should be simplified and made more nearly uniform ; that heads of schools should be invited to use a common form for reports on candidates; that application and acceptance fees, and special entrance examinations, should be abolished; that closing dates for the receipt of normal applications by all universities should be synchronized; that provisional offers of places should state the conditions in specific terms ; that candidates should be informed as promptly as possible where they stand, and be allowed reasonable time in which to accept or decline places offered to them. Birmingham has accepted these recommendations and is giving effect to them in 1959. If all universities do the same there is likely to be a substantial improvement in an inherently difficult situation.

\section{DIRECTORY OF NATURAL HISTORY AND OTHER FIELD STUDIES}

$\mathrm{O}$ behalf of the Carnegie United Kingdom Trust, the British Association for the Advancement of Seience has performed a useful service to many people in compiling a directory of natural history and other field societies.

The response to 4,000 individual inquiries made by Dr. Averil Lysaght showed that some eight hundred natural history societies flourish in Great Britain to-day. These he carefully listed and provided with a geographical index so that their work may be better known and co-ordination between them facilitated.

The publication of the Directory, so shortly after the formation of the Council for Nature, reflects the increased interest in natural history. As a comprehensive work of reference, it has attempted to include all professional and amateur societies in England, Scotland, Wales and Northern Ireland which are concerned in any way with field studies (a term which provides an umbrella for a multitude of sub- jects from interplanetary exploration to guppybreeding), or which, while not taking part in field work themselves, are active in publishing the results of such work. Medical societies have not been included, nor have societies devoted to horticulture, agriculture and forestry, nor those concerned with plants or animals purely for sporting or commercial purposes. School societies have only been listed if they publish some record of their work or carry out some special studies; it is impressive to note how many do fulfil these qualifications.

Of the societies listed, those which claim to be specifically concerned with natural history and field studies form the majority, with archrology and local history making a close second. A considerable number-somewhere about 10 per cent-are occupied with the preservation of the countryside in the broadest sense. Astronomy and meteorology are combined in a single section; geology has a section 